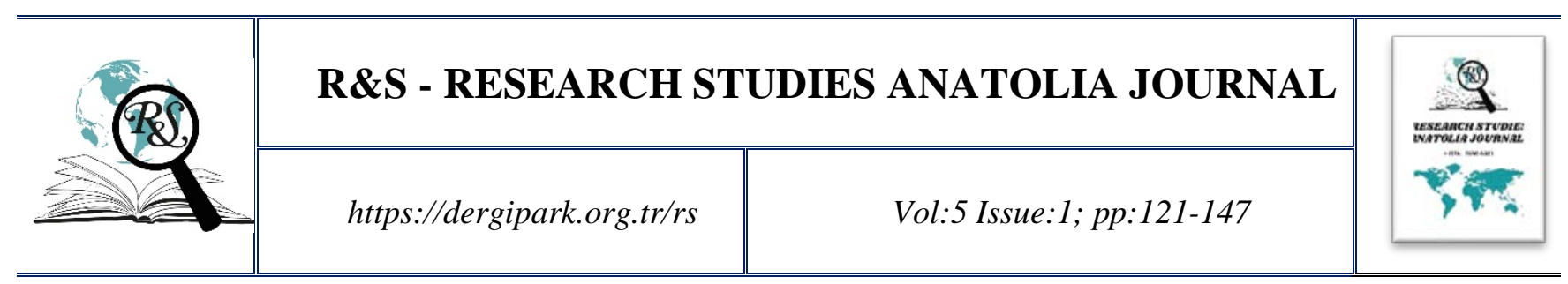

\title{
CAN BLOCKCHAIN TECHNOLOGY INCREASE PARTICIPATION IN LOCAL GOVERNMENTS? A REVIEW ON BLOCKCHAIN-BASED VOTING SYSTEMS IN LOCAL GOVERNMENTS
}

Blokzincir Teknolojisi Yerel Yönetimlerde Katılımı Artırabilir Mi? Yerel Yönetimlerde Blokzincir Tabanlı Oylama Sistemleri Üzerine Bir Inceleme

\section{Emre AKCAGÜNDÜZ}

Arş. Gör. Dr., Trakya Üniversitesi İİBF Siyaset Bilimi ve Kamu Yönetimi Bölümü, emreakcagunduz@gmail.com, Edirne / Türkiye.

https://orcid.org/0000-0003-2829-0794

Doi: $\underline{\text { https://doi.org/10.33723/rs.1048182 }}$

Akcagündüz, E. (2022). “Can blockchain technology increase participation in local governments? A review on blockchain-based voting systems in local governments”, $R \& S$ Research Studies Anatolia Journal, 5(1). 121-147.

Makale Türü: Araştırma Makalesi

Geliş Tarihi/ Arrived Date: 26.12.2021

Kabul Tarihi / Accepted Date: 19.01.2022

Yayınlanma Tarihi / Published Date: 31.01.2022 


\title{
ÖZ
}

$\mathrm{Bu}$ çalışmanın temel amacı, blokzincir temelli elektronik oylama sistemlerinin uygulanmasının yerel katılımda yaratabileceği etkileri incelemektir. Bu çerçevede çalışma üç bölüm olarak tasarlanmıştır. İlk bölümde çalışmanın kavramsal çerçevesi çizilmiştir. Bu bölümde çalışmada kullanılacak olan ana kavramlar (katılım, dijitalleşme, blokzincir, yerel yönetimler vb.) tartışılmıştır. İkinci bölümde blokzincir teknolojisinin ne olduğu, hangi alanlarda kullanıldığ ve tarihsel gelişimi açıklanmıştır. Üçüncü bölümde de blokzincir tabanlı oylama sistemlerinin neler olduğu, özellikleri ve yerel katılma yapabileceği olası katkılar tartışılmıştır. Sonuç bölümünde de elde edilen veriler çerçevesinde blokzincir temelli oylama sistemlerinin kullanılmasının yerel katılımı artıracağı yönünde bilgilere ulaşılmıştır.

Anahtar Kelimeler: Blokzincir Teknolojisi, Dijital Demokrasi, Elektronik Oylama, Dijitalleşme, e-Devlet, e-Yönetişim

\begin{abstract}
The purpose of this study is to examine the impacts of applications that use blockchain-based electronic voting systems on local participation. The study is structured in this framework to contain three sections. The conceptual framework of the study is presented in the first section. The major concepts (participation, digitization, blockchain, and local governments, among others) to be used in the contents of the study are addressed. The second chapter provides a brief overview of blockchain technology, as well as its applications and historical evolution. The third section discussed what blockchain technology was, as well as its attributes and potential benefits to local participation. The main finding obtained in this study shows that the implementation of blockchain-based voting systems will increase local participation.
\end{abstract}

Keywords: Blockchain Technology, Digital Democracy, e-Voting, Digitalization, eGovernment, e-Governance 


\section{INTRODUCTION}

Digitalization is the process of transferring physical data to a virtual environment. The reliance on places in the provision of public services has diminished since the introduction of digitization. Because of digitization, any public service may now be delivered to citizens in their preferred places / spaces rather than at government offices. This resulted in the acceleration of public services as well as increased public satisfaction. The digitization process is a dynamic process that developed due to the innovative technological approaches. The blockchain technology was first conceptualized of in 2008 as a new dimension of digitization, and its implementation began in 2009. The blockchain technology was initially used in finance with the "bitcoin" digital currency. In general, blockchain technology may be characterized as a transparent and secure data usage system (or network) that enables the exchange of data (information or data) among shareholders in digital platforms without relying on any central body. The most distinguishing aspect of blockchain technology is that data is uploaded to the blockchain system, which is made up of millions of bits, as well as its architecture, which prevents any changes to such data from being made. The application of blockchain technology in the delivery of public services has grown over time. The blockchain technology, which is presently being utilized in a range of disciplines ranging from education to medical, insurance, and finance, is expanding its applications in accordance with new advances. The implications of digital voting systems based on blockchain technology on the process of participation in local governments were investigated in this study. The core issue raised in the contents of this study is, "Could blockchain technology pave the road for democratic application in a direct manner by encouraging involvement in local government?" There are various reasons why this specific question should be addressed within the context of the study. First and foremost, Spain, the United States of America, and the Russian Federation have tested blockchain-based digital voting systems. The tests revealed that blockchain-based digital voting systems have been 
significantly proven to be successful in these countries. The first results indicate that blockchain-based voting systems will be formally employed in the near future. Efforts will be made to address the following questions within the scope of this particular study.

1. What exactly is blockchain technology? What applications do they have?

2. What is the anticipated impact of blockchain technology on local participation?

3. What are the potential drawbacks of using blockchain technology in the administration participation process?

4. Which countries used blockchain technology in the process of participation and administration? What outcomes did they achieve?

The study is designed in three sections. The conceptual framework will be discussed in the first section. The major concepts (participation, digitization, local governments, and so on) to be employed in the study's contents will be covered in this section. The blockchain technology is defined in the second chapter, along with its applications and historical evolution. The third chapter describes blockchain-based voting systems, emphasizing their features and the potential benefits they may offer to local participation. In general, the study was prepared within the scope of the qualitative research method. The qualitative research method involves the analysis of interviews, observations, and instruments (documents) to analyse any problem or evaluation. Efforts are made to tackle the problematic issues by analysing the data gathered during the qualitative research. The study will go into how to use blockchain technology in local government decision-making processes, as well as the implications of the technology on local participation (positive or negative). The sample countries that have used blockchain technology in their digital voting systems will be analysed in this framework. The articles and books on this subject, as well as the news and other written and visual media, will be scrutinized. The conclusion section will give a broad assessment based on the collected data. 


\section{RESEARCH METHODOLOGY}

Local governments are the most accessible institutions that deliver services to the general public in Turkey and throughout the world. As a result, the basic rationale in the viewpoint of local governments is to ensure that the residential area is administered by the people who live in that specific location. This is why local governments are referred to be the "cornerstone of democracy." Democracy may be described as "government of the people for the people and by the people" (Çam, 1995: 387). Although the notion of democracy has been interpreted in numerous ways over the ages, direct democratic participation remains a major concern today. Direct democracy is defined as public participation in administrative processes. Plato stated in his book "Republic (State)" that the optimal number of citizens for a direct democracy is 5040 (Platon, 2013). Today, direct democracy may be found in a number of Swiss cantons (Göktolga, 2015: 103-106). Concerns about direct democracy have long been on the forefront. The population has always been the most significant impediment to direct democracy. Participation of the people in local government decisions through direct democracy appears to be challenging if the population surpasses tens of thousands, hundreds of thousands, or millions. The regularity with which local governments make decisions does not allow for a perennial referendum. The referendum procedure is not only exorbitant, but also timeconsuming.

The primary objectives of this study is to ascertain whether or not a participatory process comparable to direct democracy is taking place in local governments by deploying blockchain technology. Electronic voting systems have been the subject of dispute at various points in time as technology has advanced. However, due to voting system security flaws, electronic voting systems had to be scrapped (Zengin, 2013: 288-291). Since blockchain technology has proven to be secure, there are currently efforts to use it into electronic voting systems. 
This research contains studies on the applicability of blockchain technology in local government administrations. The qualitative research method is used to structure the research process The research process is formed within the framework of the qualitative research method. The qualitative research method means within the context of any research "the process with subjective -interpreter for the purpose of perceiving the problems that are not previously known or noticed in any manner and tackling the natural phenomena of such problems by employing the qualitative data collection method such as analyses of the problem through observations, negotiations or documents in order to resolve the problem" (Baltac1, 2019: 369370). The printed materials / documents are thoroughly scrutinized in a systematic manner using this method. This method involves reviewing and evaluating printed documents and the information contained therein. It is the objective of documentary analysis to extract, develop, and interpret facts and their meanings within the context of the documents. There are various sub-categories of qualitative research. These are the documentary analysis and qualitative case analysis. The documentary analysis method, which is one of the subcategories of qualitative research, will be applied in this study. In this method, printed materials and documents are thoroughly evaluated in a systematic manner. These printed items, as well as the information they contain, are examined and analysed. The aim of documentary analysis is to extract, develop, and explicate the relevant facts from any document (Kiral, 2020: 173-174). In this regard, academically noteworthy articles and books from Google Scholar, Web of Science, ACARINDEX, EBSCO, and TÜBTAK tr are scanned initially. Following that, the PhD dissertations on the issue as well as the news in the media are analysed. The data is then analysed in a systematic manner, and the key questions raised within the scope of the study are addressed. 


\section{CONCEPTUAL FRAMEWORK}

The study's conceptual framework is made up of concepts such as blockchain technology, e-government, digital democracy, local democracy, local governments, and local participation. The key objective of the research is to determine whether or not there are secure voting systems in place following the introduction of the digitization process. As a result, digital democracy is the major emphasis of the research. The participation of individuals who live their lives in any governmental area by way of digital means is referred to as digital democracy (that is to say, there exist no intermediaries) (Zengin, 2013: 274-276). In fact, digital democracy may be referred to as direct democratic practices in the twenty-first century. The first direct democratic implementations may be traced back to Ancient Greece. The primary objective of direct democracy is the direct participation of all citizens in the administration process. Because of the massive population, direct democracy cannot be applied at all times nowadays. For example, through a referendum, direct democracy may be applied in a municipal region with a population of more than three million people. However, counting the votes, ballot security, nominated officials, and the payments to be made available for such officials as part of the referendum process all cost time and money. Therefore, it is now being debated how direct democracy might be used in the most practical and secure way. At this stage, voting techniques based on blockchain technology are gaining traction. The fact that blockchain technology has been proven to be secure implies that digital democracy will flourish as a result of this technology.

Blockchain technology is a system with several major purposes. If shareholders agree it, a decentralized, transparent, and controlled register system exists in this system. A system like this was created in 2008 to expedite the transfer of large sums of money in the finance industry. Through blockchain technology, an individual known as Satoshi Nakamoto built the architecture of the virtual monetary system "Bitcoin." Although the initial promise of 
Blockchain technology was to bring some financial benefits, this technology has the potential to be used in a variety of industries ranging from education to medical care and personnel operations to commerce. The primary aim of blockchain technology is to abolish the excessively centralized powers of centralized authoritative bodies (such as the states, banks, clearing houses et cetera). These powers are dispersed among shareholders via blockchain technology, resulting in a decentralized, transparent, and democratic framework (Tüfekçe \& Karahan, 2019: 159). Blockchain technology has been defined in a number of ways. For instance, Nakamoto (2008: 1) characterized blockchain technology as a "structure that shares and registers data with shareholders in a manner that is not dependent on a centralized unit, where the system data are inscribed on data units known as "blocks." It is defined by Nofer, Gomber, Hinz, and Schiereck (2017: 183) “as the entire data set established by the so-called block system in the form of multiple chains on which data is entered and safely kept.” Because blockchain technology links hundreds of blocks together, it is almost impossible to make changes or manipulate the system in any manner. Therefore, efforts are being made to use blockchain technology, particularly in the digital voting process.

E-government is a concept that has been put into practice to make it easier for citizens to receive public services. E-government is defined as the provision of public services in an electronic environment. E-government is a dynamic application that has been developed not only in Turkey but also around the world. Today, an e-government application that delivers public services at any location where the internet is available via smart phones and computers provides services in a range of disciplines. E-government applications make it simple to access services ranging from subscription operations to tax payments, medical services, and education. It is expected that digital voting will be included in e-government apps in the near future. Any governmental policy will easily be voted through the e-government platforms. 
The concepts of local governments, local participation, and local democracy are all intertwined. Local governments are the closest units to residents that deliver services. The origin of the philosophy of local governments is to hear the people's demands and claims in a direct and much more comfortable manner. Therefore, in addition to the other criteria, local governments have been constituted that take population into account. Local participation is at the heart of the basics of local governments. Local participation entails the involvement of all local shareholders in the formulation of public policies applicable at the local level, as well as the process of putting such policies into effect. Participation of all shareholders in the practices of local governments, including citizens, civil society organizations, pressure groups, and associations, is necessary for local participation Because the most widely accepted definition of democracy is "government of the people by the people" (Çam, 1995: 387). Local governments, local participation, and local democracy are three essential concepts in this setting. The full participation of the people in the decisions made by local governments may result in interaction between these three concepts. As a result, it is critical for inhabitants in any local government region to participate in all decisions that are made. Voting systems based on blockchain technology will provide new dimensions to referendums in terms of security and practicality.

\section{THEORETICAL FRAMEWORK}

The study's theoretical framework is based on e-governance. Before delving into the concept of e-governance, information about governance should be presented. Because the notion of governance has evolved in tandem with technical improvements. Blockchain technology might be viewed as a new dimension of the governance notion.

By the early 1990s, the concept of governance had constituted. The governance notion, which was initially mentioned in reports released by international institutions (the United Nations, the World Bank, and the International Monetary Fund), piqued the academic 
community's interest. The governance concept was presented as an alternative to orthodox Weberian government understanding's excessively rigorous and centralized structure. The term governance has evolved to refer to shared government procedures in which all shareholders are involved (Sobac1, 2007: 221-222).

The fundamental features of governance include consistency, transparency, accountability, equitability, adherence to laws and participation (TESEV, 2008: 7-8). Consistency refers to the reliability of decisions made throughout the administration process and promises made by the administrative authorities. If there is any contradiction in the judgments of the administrative authorities, the public's confidence will be warped. There appear to be issues with the administration process in this instance. To avoid such governance issues, the administrators' words and actions must be totally consistent. Transparency refers to the openness of the government process to the public. Any decision-making process, in particular, should be easily monitored. At all phases of governance, the information should be made available to those who seek it. Accountability refers to the responses of the administrative authority to queries about how resources are used throughout the administration process. During whole administrative process, the administrators are accountable for their operations, activities, and actions of any kind. Wherever possible, they should be held accountable for their commitments. Equitability is defined as equally balanced behaviour for all parties concerned, with no bias for any institution or individual in view of decisions taken during the administration process. The principle of equitability should not be placated at any stage of governance, from the distribution of public resources to personnel recruitment. The conformity with the legislations in the administration process is referred to as law adherence. All activities and actions undertaken as part of the administration process must be in accordance with the constitution and laws. Participation refers to the participation of the people, as well as any other establishments (civil societies, associations, foundations, and so on) in the administration process. The broader the 
participation, the fewer the difficulties that may arise during the administration process (TESEV, 2008: 9-12; Özer, 2006: 65-73; Kayıkçı, 2014: 106-108).

E-governance evolved from the growth of the governance concept as a result of the digitization process. The interaction among shareholders has substantially improved as a result of advancements in internet and information and communication technology. Individuals, groups, civil societies, foundations, associations, political parties, and other shareholders have come to communicate with one another more easily as a result of improvements in technology, notably the internet. As the internet has been more widely used, online data exchange among shareholders has expanded. Data may be shared more easily via PCs, mobile phones, and tablets at any location where the internet is available. The ease with which people and groups may share information online aided the building of networks. The administration process was impacted by such networks. In lieu of face-to-face meetings, ambiances have been created electronically to hold meetings between people or groups in the venues they attend when developing public policy. In reality, governance is a type of network governance. Shareholders can easily participate in the administration process via networks developed on the internet or other virtual environments. Thus, a transparent, accountable environment is created in which anyone can participate. E-governance should not be regarded as a method for enhancing communication and interaction among shareholders in a virtual setting. E-governance covers a wide range of themes, from public services to policymaking. In identifying the problems observed in the provision of public services, executive, legislative, and judicial operations, citizen satisfaction, political engagement, decision-making, and numerous other subjects, egovernance takes centre stage (Demirel, 2010: 69-71; Doğan \& Ustakara, 2013: 6-7; Pandey \& Risal, 2020: 94-95).

Blockchain technology is designed to allow for the distribution of authority among shareholders rather than a centralized authority. The shareholders are in charge of the 
procedures and operations carried out using blockchain technology. A central authority's inspection and approval are not necessary. This ensures that the procedures and activities are carried out by the shareholders involved rather than a sole centre (Allen \& Berg, 2020: 1-6). Blockchain technology may also be regarded as a kind of "network governance." In the absence of a central authority (as a supervisory and approving mechanism), blockchain technology transitions a much more horizontal administration process rather than a traditional state-centred and hierarchical administration paradigm. With the introduction of blockchain technology, the administration structure known as Decentralized Autonomous Organizations (DAO's) was launched. This is the more sophisticated form of the e-governance scheme (Zwitter \& Hazenberg, 2020: 4-9; Atzori, 2017: 46-47).

\section{AN OVERVIEW OF BLOCKCHAIN TECHNOLOGY}

Contrary to popular belief, Blockchain technology did not originate with Satashi Nakamoto's paper titled "Bitcoin: A Peer-to-Peer Electronic Cash System," which provided insight of "Bitcoin" in 2008. The development of this technology is based on many studies that take place at different times.

The historical background of the blockchain technology may be traced back to the distributed recording" technology, also known as the "Distributed Ledger." The first academic study on this subject was published in 1976, with the title "New Directions in Cryptology." Following that, the process proceeded with the introduction of difficult-to-break codes in accordance with advances achieved in the field of cryptology. Stuart Haber and Scott Stornetta's article "How to Time -Stamp on a Digital Document?" published in 1991 analysed the methods for scripting a time code on data. David Chaum developed a new financial payment model in his studies in 1995. The proposed model alluded to concepts such as "Electronic Cash" or "Digital Currency." Such concepts helped to the creation of the blockchain system, which monitored e-cash schemes and detected double spending using protocols. Adam Back 
introduced another concept called "hashcash" in 1997, which gave methods for detecting spam e-mails. This cleared the path for the development of the money depositing concept known as b-money, which was developed by Wei Dai based on the matching network after developing Hashcash (Sarmah, 2018: 23-24). All of these improvements culminated in an article written in response to the challenges experienced during the 2008 economic crisis. In 2008, the pseudonym Satoshi Nakamoto released an essay titled "Bitcoin “A Peer-to-Peer Electronic Cash System ". In general, the essay advocated a multi-party, difficult-to-copy money transfer system that does not rely on central authority or confidence (Sarmah, 2018: 23-24; Nakamoto, 2008: 2-4).

In early 2009, an open source program was released to implement Nakamoto's bitcoin scheme. Thus, the first bitcoin network was built. One point should be emphasized here. The blockchain technology was maintained at the same level as bitcoin. In several cases, a comparable misconception occurred. Blockchain is the name of the technology that enables the general applicability of bitcoin. Bitcoin is digital money that was created via the use of blockchain technology. Bitcoin has grown in popularity since it was designed to provide transparent and decentralized money transfer services. The popularity of bitcoin has resulted in the development of electronic wallet software. Users may now transfer bitcoin using any computer, mobile phone or online application thanks to this unique invention. The foundation of the Ethereum platform in 2015 was the key event that prepared the way for the growth of blockchain technology following the bitcoin application and its broad implementation. Ethereum is built on a "smart contract" mechanism that allows parties to execute mutual transactions or contracts. Ethereum has grown in popularity because it provides a significantly safer, faster, and more useable and efficient environment for blockchain technology. As a result, blockchain technology, the roots of which were initially set in 1976 with the concept of 
Distributed Ledger, is now extensively employed in a variety of disciplines (Sarmah, 2018: 2324; Metcalfe, 2020: 78-80).

The innovations put forward by the system cannot be effectively appreciated until the functions or operating logic of the blockchain technology is clearly understood. Therefore, the functions and operating logic of blockchain technology should be discussed briefly. Blockchain is a system formed by combining blocks that are made accessible for data inclusion for an individual with the advent of time. Once uploaded to a blockchain system in the form of a chain, the data block cannot be deleted or amended. Until the block is completely filled with information (that is, data) on which it is scripted, it is added to the other blocks through an algorithmic link. Thus, a data chain (the blockchain) develops. To better understand the system, consider the following example: Deem the blockchain's blocks to be a "book of records." It is the same way that every book of records converts into a new page for new entries, and the blockchain does the same for any block. Transactions and operations performed on the ledger with several participants are recorded in such a way that the serial number (the so-called name of the page that defines the page), date, and signature are included. Any recorded input is inscribed on the block with the time, serial number, and shareholder identification. The resulting block is added to the blockchain, and the data stored on it is saved in the system. This is disclosed not just to shareholders, but also to anyone participating in the blockchain (depending on privacy or transparency) (Avunduk \& Aşan, 2018: 371-373; Özaltın \& Ersoy, 2020: 750-753). 


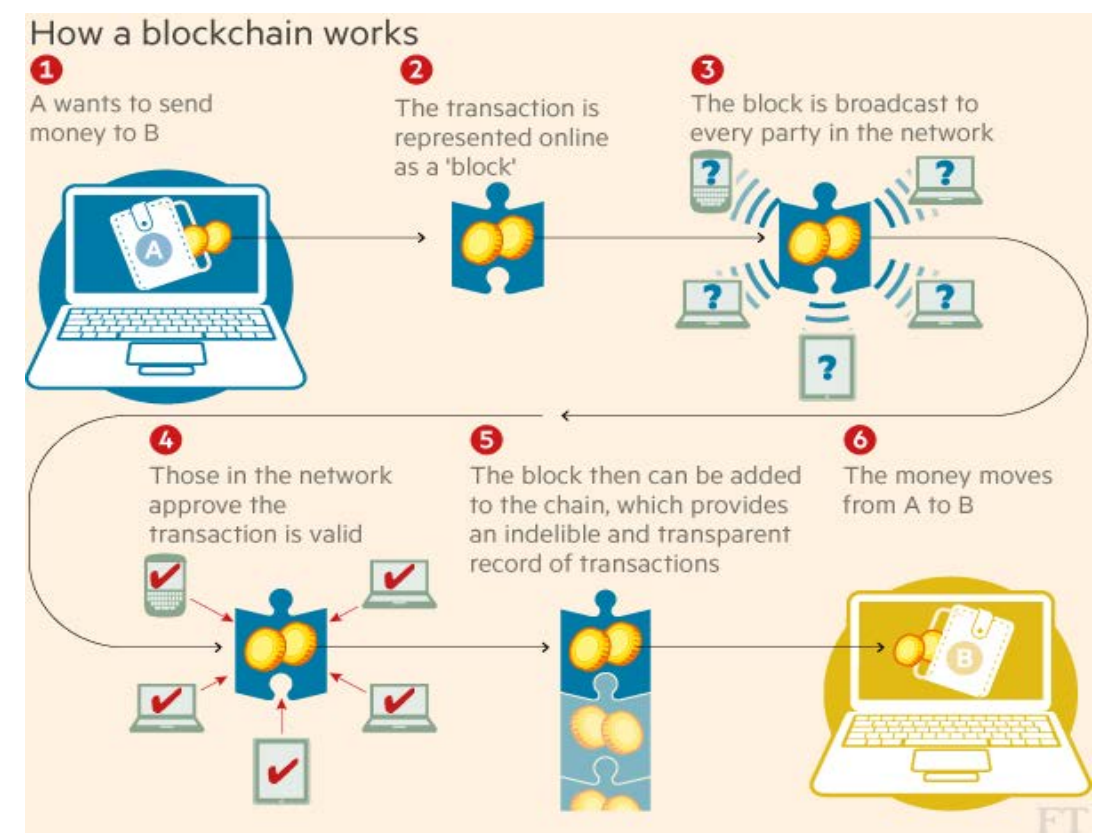

Figure 1. Blockchain Working System

(Joshi, 2016)

Figure 1 illustrates how blockchain technology works. Figure 1 shows a person transferring money to another via blockchain technology. Any block should be defined initially for this reason. Following the definition of the block, it is dispersed to all shareholders in the network. Following such distribution, the operation specified in the block is accepted by the network's shareholders. Following the block's acceptance, it is uploaded to the blockchain. As a result, the money transfer is completed. Several aspects should be stressed after clarifying the concerns expressed in Figure 1. First and foremost, if the operation depicted in Figure 1 is evaluated, there is no power holding the authority in its hands. The permission of all shareholders (inside the network) is required for the purpose of money transfer. Blockchain technology, if paid attention to, represents a transparent, participatory and decentralized process.

\section{USE OF BLOCKCHAIN TECHNOLOGY IN ELECTRONIC VOTING SYSTEMS}

In the twenty-first century, information and communication technology have permeated all aspects of existence. Technological developments must have been directed at making people's 
lives easier. Political engagement and policymaking procedures are both difficult challenges in traditional sense. Because of the rising population, representative democracy is gaining traction in lieu of direct democracy. In a representative democracy, a predefined number of citizens are represented by a representative in the process of political decision-making or the formulation of public policy. Various criticisms have been levelled in this instance. In representative democracy, for example, it is observed that representatives act against the interests of the people they represent. Direct democracy should be re-implemented to avert such issues and others of a similar type. Rapid advancements in information and communication technology (especially the internet) have sparked debate about whether direct democracy is applicable. As a result of such debates, the implementation of e-voting systems has commenced (Durukal \& Öztürk, 2021: 42-45).

E-voting was in use in a number of countries and significant experience had been garnered. For example, it has been implemented in India since 2004 to combat fraudulent voting practices and ballot box theft. Similarly, Brazil was one of the first countries in the world to deploy electronic voting systems. Brazil, which designed and deployed a voting system for the first time in 1996, has moved to a safer electronic system after tackling the problems it encountered in 2002 (Akın, 2006: 40-41). Estonia was one of the first countries to use an electronic voting system. Estonia, which deployed an electronic voting system in 2005, is striving to improve the system based on its experience (Clarke\& T. Martens, 2016: 130-132; Drechsler \& Madise, 2004).

When the electronic voting systems used across the world are scrutinized, various issues are discovered. The International Institute for Democracy and Electoral Assistance (International IDEA), which performed research on this subject, described the primary issues encountered with electronic voting systems in the following manner (IDEA, 2011: 9):

1. Records kept throughout the voting process that is incomplete or insufficient. 
2. Data loss as a result of delinquencies following the elections

3. Ballot officers tampering with the votes

4. Election-related changes brought about by hacking and spyware

5. Storing and stowing the voting results

6. Issues encountered during the re-counting of votes

7. Problems arisen in relation to the maintenance and storage of the tools and instruments used in electronic voting.

The voting systems based on blockchain technology may provide solutions to the challenges mentioned above in electronic voting systems. The most distinguishing aspect of blockchain technology is its ability to thwart hacking by interconnecting blocks together. This is due to the fact that each block is joined together, and the individual seeking to block the system must solve tens of sophisticated algorithms that are tied to each other. Any addition to the block makes it tougher to hacking. The ease of storing is a significant characteristic of blockchain technology. Data may be appropriately stored in a digital environment. Changes to the data inscribed in the blocks are impossible in the system to be established in the blockchain technology without the approval of the shareholders. Based on the type of blockchain to be used, it is almost impossible for non-shareholders to make any changes to the blocks. Furthermore, data loss is nearly impossible in the blockchain system. The benefits provided by the blockchain-based voting system may be augmented.

Various countries throughout the world have implemented blockchain-based electronic voting systems. For example, the Spanish political party Podemos asked its 155.000 members to vote on party-related matters using Agora Voting, an electronic voting system based on blockchain technology, from February 4 to 11, 2017. Agora Voting is a secure, open source, end-to-end verifiable voting system based on blockchain technology. Agora Voting was developed as part of the D-CENTO (Decentralized Citizens Engagement Technologies) 
Project, which was funded by the European Commission. This project was implemented in order to enhance democratic participation through the use of a safe, transparent, swift, and efficient voting method. Agora Voting provides a transparent, secure, and flexible election environment that is encoded by the web browser and concealed even from people in charge of the elections (Opendemocracy, 2017; Intelligent Cities, n.d.).

Follomyvote is another application that has developed an electronic voting system based on blockchain technology. Followmyvote is a blockchain-based system that is being adopted in a number of US states. Followmyvote, with the slogan "The truth shall set you free, "seeks to develop effective communication among its members. Followmyvote strives to keep the voting process digitally secure, quick, and efficient. Followmyvote develops a blockchain-based standardized, accurate, fair, trustworthy, and globally acceptable voting system, specifically for use in political elections and referendums throughout the world. Figure 2 shows how the blockchain-based voting method of followmyvote works (Followmyvote, 2021). 


\section{Blockchain Voting}

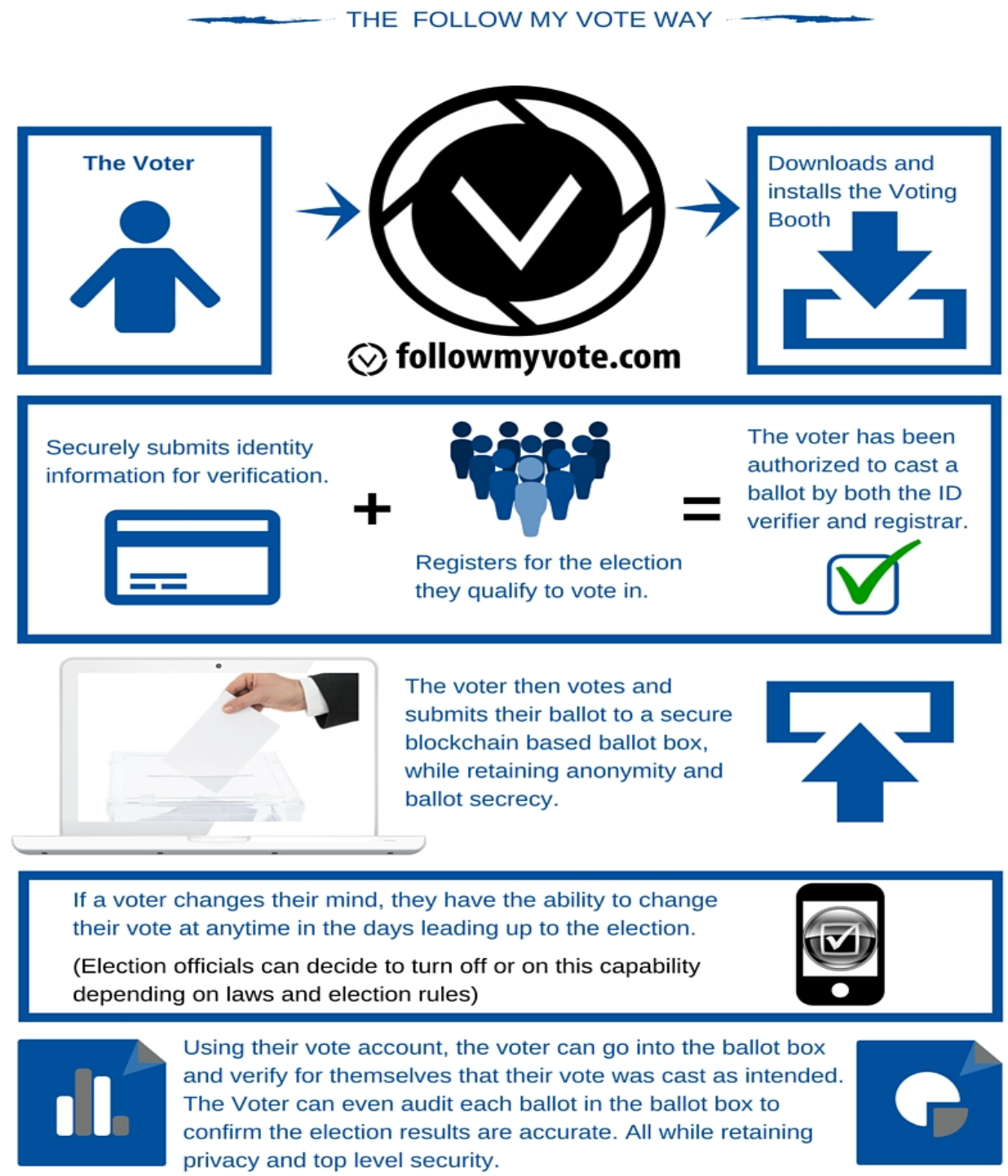

Figure 2. Followmyvoteblockchain-Basede-Voting Working System

(Followmyvote, 2021)

Russia is another country that has implemented a blockchain-based voting system. Russia used the blockchain-based voting system developed by the company Waves as a test application in the states of Kurskaya and Yaroslavskaya. There are various aspects of the Waves Company's blockchain-based voting system: Controllability, Confidentiality, Reliability, Consistency, Verifiability, User-Friendliness, Consistency, and Throughput. Controllability allows pre-defined authorized persons to access the system. Other than the 
previously defined individuals, no one else may meddle with the system. Citizens who are eligible to vote are safely registered in the system using smart contracts after going through the relevant formalities. Confidentiality is maintained by using strong encryption during the voting and counting operations. As a result, any external interference in the voting and counting processes is rendered impossible. The smart contracts block unauthorized users from voting. The outcomes of the votes are safeguarded by cryptographic algorithms, and data consistency is maintained by adding blocks to the chain. The shareholders, not the central authority, assure verifiability. Furthermore, smart contracts make it easy to verify data. Furthermore, the system may be described as user-friendly. Because of blockchain technology, the results of the voting are not recorded in a central location. The data is grouped in a decentralized manner, with the stockholders in control of such data. This demonstrates the system's consistency. The Waves Company's blockchain-based voting system is a cutting-edge solution in terms of efficiency and speed. Waves' blockchain-based technology can process about 1000 data points every second (Wavesenterprise, 2021). As can be observed, the "Waves Enterprise Network" developed by Waves Corporation and applicable in Russia is one of the most advanced blockchain-based voting systems. Russia intends to broaden the system's application and utilize it throughout the country.

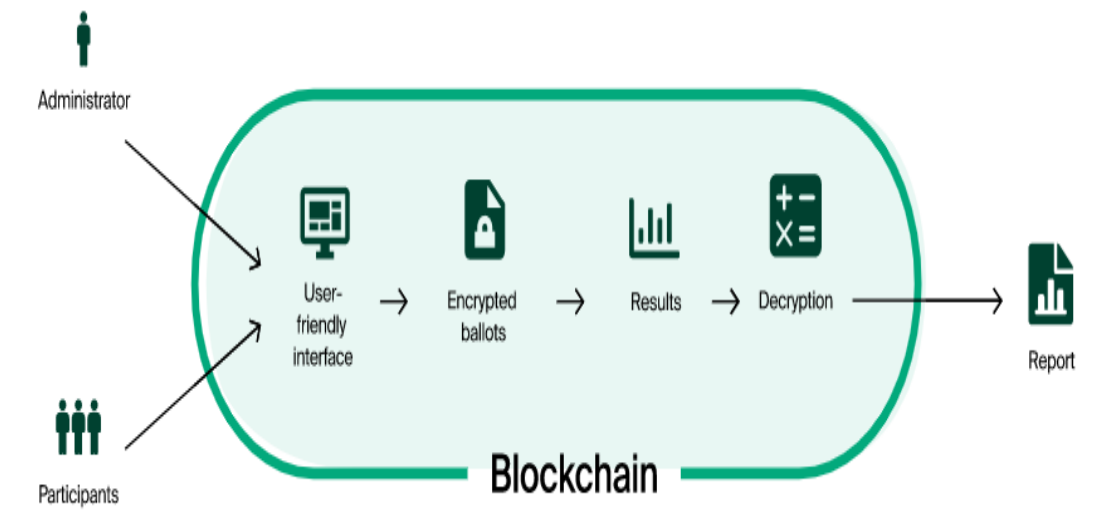

Figure 3. Waves Enterprise Blockchain Based Voting Working System

(Wavesenterprise, 2021)

$\mathbf{R} \& S$

Research Studies Anatolia Journal

Volume:5 Issue:1, January 2022 
In the first priority, the blockchain-based electronic voting systems described herein, notably Agora Voting Followmyvote and Waves Enterprise, were utilized in small scale localities with low population density. The pilot applications on these three platforms achieved significant results. Voting systems based on blockchain technology may be better exemplified. Due to the limited number of words available for this study, the three most commonly used and significantly successful platforms were analysed.

\section{DIRECTIONS FOR FUTURE RESEARCHERS}

Blockchain technology is still in its early stages. However, literature searches undertaken over the course of the study revealed that blockchain technology has been employed in tens of various areas ranging from education to health, finance to insurance. This suggests that blockchain technology will be used in more industries in the near future. Therefore, a greater knowledge of blockchain technology and its use in areas that may improve people's lives is unavoidable. As a result, countries must investigate methods to use blockchain technology to the delivery of public services. This study proved that blockchain-based voting systems are secure and reliable for promoting democratic participation. By developing pilot applications, Blockchain-based voting systems will most likely be developed into a system that inculcates trust in everyone by developing pilot applications.

\section{CONCLUSION AND RECOMMENDATIONS}

The research conducted as part of this study revealed that blockchain-based electronic voting technology was in use and had proven to be successful. The blockchain technology was discovered to be in use in 89 key industries throughout the course of the study (education, medical, finance, insurance, energy, tourism, music, advertising, supply chains, title deeds, identification, border checks), anti-smuggling, human resource management, taxation, and transportation). 
It has been observed as a result of the study that blockchain technology will increase the local participation. There are several reasons for this. To begin with, whether or not direct democracy is appropriate in local governments has been a point of contention all across the world. Applying for the general public's opinion in the implementation of local government decisions, in particular, is unavoidable for the development of democratic participation. However, due to the high population density and the amazingly large area of territory on which any particular local government is located, it is impossible to rely on public opinion in all matters. Referencing any subject to the public through a referendum is not only costly, but also time demanding. In this case, despite attempts to establish electronic voting systems, individuals are concerned about the possibility of system hacking and centralized authority control of the system. Three significant breakthroughs for electronic voting are provided by blockchain technology. First of all, blockchain technology has a decentralized working order. That is, the system does not allow for data collection at a single place. All shareholders have access to the data. Data is stored in a distributed manner. As a result, all shareholders now have access to the data. Thus, the central authorities have no opportunity to rig the elections (through changes to votes casted). However, the most important feature of blockchain-based voting systems is that the votes cast are linked with one another via complicated algorithmic encryption in the form of blocks. Blocks chained to each other using complex and lengthy encryptions are unified as long as they are chained. Anyone with the intention to hack the system can do so if the passwords within the chains are all broken. This looks to be an insurmountable task. It is impossible to hack the blocks linked together by hundreds of intricate encryptions in any network where each vote is added to the system in the form of a block. The point here is to underline that the key characteristic of the blockchain-based voting system cannot be hacked in any manner. Finally, blockchain-based voting systems make data storage simple. Such data are stored under the supervision of the shareholders, rather than in a storage 
instrument, as in the case of traditional voting systems. This, along with many other characteristics, improves the usability of blockchain-based voting systems. Voting systems based on blockchain technology will be utilized more frequently since they are faster, easier to access , and much safer. Because citizens will be able to participate in elections, questionnaires, and referendums from any place (home, office, park, garden and open space).

In the Japanese city of Tsukuba, a blockchain-based voting system was introduced in 2018 for a social development issue. Residents of the city were first handed cards with 12 digit numbers. Each of these cards was established for people who may then use their voting rights. Each vote cast by citizens by reading the cards was recorded to the blockchain system designed by the company LayerX. The election process was thus completed. Remarkable progress has been made in this election (Berman, 2018). Sierra Leone held elections in March 2018 using a blockchain-based voting system. With the assistance of the Swiss company Agora, 280 polling booths were built in Sierra Leone's densely populated western region. Each vote cast was recorded on the blockchain network developed by the Agora company to ensure the security of the ballots and their accurate counting. As a result, any fraudulent activity was averted. Sierra Leone's National Electoral Commission reported that the system produced consistent outcomes (Perper, 2018). Countries such as Russia, the United States, and Estonia are now striving to develop a blockchain-based voting system.

As a result, voting systems based on blockchain technology are currently being used for general purposes. The pilot applications yielded significant results. The impact of blockchainbased voting systems on increasing political participation cannot be debated. The general public's demands from local governments, in particular, shall be routed to administrative units as soon as possible. Aside from that, whenever an issue concerning public policy is debated, open polls will be established in a timely and secure manner, with the involvement of everyone. Several points, however, should be highlighted. To begin, blockchain technology is presently 
in development. Several problems have been identified during pilot applications. These issues must be addressed. The almost negative outcomes reported in the countries where the electronic applications were first introduced resulted in people's dissatisfaction with blockchain-based electronic voting systems. Furthermore, hackers or so-called cyber-terrorists are likely to manipulate election results through deceptive applications such as virus software, bogus websites, ID theft, spyware, Trojan horse programs, and so on. Any vote cast through the use of the blockchain-based voting system cannot be changed once it is uploaded to the blockchain. This implies that any vote cast inadvertently is irrevocable. For example, there is no method to regain a vote if a person is coerced and is subjected to any form of suppression to vote for someone. As a consequence, while the blockchain-based voting method may pose a number of issues, it is already being implemented. As a consequence of this research, it has been discovered that blockchain-based voting systems are continuously being developed, and efforts are being made to resolve any issues that may arise. Blockchain-based voting systems will be much improved in the near future and will be used effectively in political participation processes in local governments.

\section{REFERENCES}

Akın, M. (2011). Elektronik oy verme sistemlerinde güvenlik: deneyimler ve Türkiye için öneriler. Istanbul University Econometrics and Statistics e-Journal, 0(3), 32-47.

Allen, D. \& Berg, C. (2020). Blockchain governance: what we can learn from the economics of corporate governance. SSRN Electronic Journal, 3(1). 1-10.

Atzori, M. (2017). Blockchain technology and decentralized governance: Is the state still necessary? Journal of Governance and Regulation, 6(1). 45-62.

Avunduk, H., \& Aşan, H. (2018). Blok zinciri (blockchain) teknolojisi ve işletme uygulamaları: genel bir değerlendirme. Dokuz Eylül Üniversitesi İktisadi ve İdari Bilimler Fakültesi Dergisi, 33(1). 369-384. 
Baltac1, A. (2019). Nitel araştırma süreci: nitel bir araştırma nasıl yapılır? Ahi Evran Üniversitesi Sosyal Bilimler Enstitüsü Dergisi, 5(2). 368-388.

Berman, A. (2018) Japanese City Tsukuba Trials Blockchain-Based Voting System. Cointelegraph. $\quad$ https://cointelegraph.com/news/japanese-city-tsukuba-trialsblockchain-based-voting-system.

Çam, E. (1995). Siyaset bilimine giriş. DER Publication.

Clarke, D. \& Martens, T. (2016). E-voting in Estonia. In Real-World Electronic Voting: Design, Analysis And Deployment, Auerbach Publications, 129-141.

Demirel, D. (2010). Yönetişimde yeni bir boyut: e-yönetişim. Türk İdare Dergisi, (466). 6593.

Doğan, K. C. \& Ustakara, F. (2013). Kamuda bir yapılanma dönüşümü olarak e-devlet ve eyönetişim ilişkisi üzerine. Global Journal of Economics And Business Studies, 2(3). 111.

Drechsler, W. \& Madise, Ü. (2004). Electronic voting in Estotnia. In Electronic Voting and Democracy. Palgrave Macmillan, 97-108.

Durukal, O. \& Öztürk, N. K. (2021). Elektronik oylamada blokzincir teknolojisi kullanımı, In Kamu ve Özel Sektörde Bokzincir Teknolojisi (41-54). Nobel Publication.

Followmyvote (2021) What the followmyvote is. https://followmyvote.com/.

Göktolga, O. (2015). Demokrasinin demokratikleştirilmesi: yerel doğrudan demokrasi uygulamaları. Birey ve Toplum Sosyal Bilimler Dergisi, 4(2). 97-116.

Intelligent Cities (n.d.). Agora voting: an open source online voting software. Retrieved November 19, 2021, from https://icos.urenio.org/applications/agora-voting/.

International Institute for Democracy and Electoral Assistance-IDEA, (2011). Introducing electronic voting: essential considerations. Sweden: International IDEA Publications Office. 
Joshi, N. (2016) What is blockchain technology and who is using it? Allerin. https://www.allerin.com/blog/what-is-blockchain-technology-and-who-is-using-it.

Kayıkçı, S. (2014). Türkiye'de yönetimden yönetişime geçiş: yüksek çevre kurulu örneği. Aksaray Üniversitesi İktisadi ve İdari Bilimler Fakültesi Dergisi, 6(2), 105-114.

Kıral, B. (2020). Nitel bir veri analizi yöntemi olarak doküman analizi. Siirt Üniversitesi Sosyal Bilimler Enstitüsü Dergisi, 8(15), 170-189.

Metcalfe, W. (2020). Ethereum, smart contracts. In Blockchain and Crypt Currency: Building a High Quality Marketplace, Springer, 77-93.

Nakamoto, S. (2008). Bitcoin: A peer-to-peer electronic cash system. 08 29, 2020 retrived from: https://bitcoin.org/bitcoin.pdf. 1-9

Nofer, M., Gomber, P., Hinz, O., \& Schiereck, D. (2017). Blockchain. Business \& Information Systems Engineering, 59(3), 183-187.

Opendemocracy (2017). Agora voting/nvotes. https://www.opendemocracy.net/en/caneurope-make-it/agora-votingnvotes/.

Özaltın, O. \& Ersoy, M. (2020). Kamu yönetiminde blokzincir kullanımı: d5 örneği. Nevşehir Hacı Bektaş Veli Üniversitesi SBE Dergisi, 10(2), 746-763.

Özer, M. A. (2006). Yönetişim üzerine notlar. Sayıştay Dergisi, (63). 59-89.

Pandey, D. L. \& Risal, N. (2020). E-governance: A study of the concept and implementation in the emerging economy. Corporate Governance and Sustainability Review, 4(2), 93-101.

Perper, R. (2018) Sierra Leone just became the first country in the world to use blockchain during an election. BusinessInsider. https://www.businessinsider.com/sierra-leoneblockchain-elections-2018-3.

Platon (2013). Devlet. Bordo Siyah Publication. 
Sarmah, S. S. (2018). Understanding blockchain technology. Computer Science and Engineering, 8 (2). 23-29.

Sobac1, M. Z. (2007). Yönetişim kavramı ve Türkiye'de uygulanabilirliği üzerine değerlendirmeler. Yönetim Bilimleri Dergisi, 5(1). 219-235.

TESEV (2008). İyi yönetişim el kitabı. TESEV Publication.

Tüfekçe, A., \& Karahan, Ç. (2019). Blokzincir teknolojisi ve kamu kurumlarınca verilen hizmetlerde blokzincirin kullanım durumu. Verimlilik Dergisi, (4). 157-193.

Wavesenterprise (2021) How to work blockchain based e-voting system? blockchain advantages, voting process. https://wavesenterprise.com/products-and-services/voting.

Zengin, M. A. (2013). Bilgi iletişim teknolojilerinin demokrasi içerisinde kullanımı ve dijital demokrasiye geçiş. Ankara Hacı Bayram Veli Üniversitesi Hukuk Fakültesi Dergisi, 17(4), 271-304.

Zwitter, A. \& Hazenberg J. (2020) Decentralized network governance: blockchain technology and the future of regulation. Frontiers in Blockchain, 3(12), 1-12. 